impossible. There was, however, a valuable and finely staged exhibit showing improvement in cereals, which included mature growing plants, of varieties of wheat, oats and barley that were grown approximately a hundred years ago and an equal number of well-known modern rarieties.

With the increasing recognition of the value of protective foods, horticultural crops in many ways now rival agricultural crops in importance, and the value of scientific research in horticulture is rapidly attracting attention. Under modern competitive conditions high quality produce only is demanded, and this is unobtainable from neglected and pest-ridden orchards and gardens. This was exemplified partly in an exhibit designed to stress the differences between the old-fashioned ill-kept orchard and the modern plantation run on commercial and scientific lines, and partly in an exhibit of vegetables, salads and fruits grown in the intensively farmed area of Buckinghamshire.

Finally must be mentioned the garden in front of the scientific building, which was laid out by the University Department of Horticulture to a design prepared by the Department of Landscape Architecture. A magnificent centre bed displayed the carpet bedding fashion of a century ago, whilst two flanking beds showed a modernistic treatment.

The entire exhibition was a notable success, informative and stimulating in its portrayal of the interest of agricultural and horticultural research and of its value in practice, and not only colourful but also satisfyingly beautiful in the artistry of its design and production. The exhibit was worthy of the Royal Centenary Show and set a standard which it will not be easy to maintain.

\title{
OBITUARIES
}

\section{Dr. W. M. Childs}

$\mathrm{D}$ R. W. M.:CHILDS, principal of University College during 1903-1926 and first vice-chancellor of the University of Reading during 1926-1929, died at his residence, Grimsbury Bank, Hermitage, Berkshire, on June 21, aged seventy years.

In the history of the modern English universities, no one has played a part corresponding at all closely to that of William Macbride Childs. With the exception of Reading, the universities which have arisen during the past fifty years have developed from earlier colleges, with an established tradition of teaching and research as the justification for their academic independence. But the whole history of the movement which created the University of Reading is comprised within a period of less than half a century. The institution to which Childs went as a lecturer in 1893 was little more than a centre at which work initiated by university extension classes could be carried to a further stage; it had scarcely the rudiments of an academic organization, and its financial resources were meagre and uncertain. It is the supreme distinction of Dr. Childs that he saw the possibilities latent in this small and anomalous institution, devoted his life to their realization, and impressed the stamp of his personality on the college and university which came into being through his efforts.

Childs was enabled to succeed in what seemed at first a hopeless task by the intensity of his belief in his ideals, and by his power of imparting his own convictions to others who could help him. He possessed the rare faculty of constructive imagination. To him, the ideal university was a community of teachers and students, informed by a lifo and spirit which transcended the achievements of individuals. From the pursuit of this ideal he never turned aside. But unlike many idealists, he had the habit of mind which finds pleasure in practical details, and his patience could never be exhausted. He planned every stage in the long process through which the eollege at Reading came to university independence. The addition of one department after another to the nucleus of a college with which his work began, the creation of an academic organization, the establishment of halls of residence for students, were all, to him, matters of intense personal interest. For thirty years he concentrated the abilities of one who was by nature a man of affairs upon the details which gave form and substance to an ideal.

In course of time, the influence of Childs' personality and work spread beyond the circle of his immediate associates. It was his devotion to his chosen task, and the transparent sincerity of his conviction that the creation of a university in Reading was a work which any man might bo proud to advance, which brought to the college the endowments essential to its growth. On the general history of the modern universities, his influence, though indirect, was real. The most original part of his work at Reading was the establishment of a system by which all students not drawn from the immediate neighbourhood live in halls of residence. To-day, the value of life in a collegiate environment for students of a modern university is recognized everywhere. But when Childs conceived the idea of basing the University of Reading upon a residential system, little had been done in this direction elsewhere, and the opening of Wantago Hall in 1908 was the first effective demonstration of the fact that life under conditions similar to those which have prevailed for centuries at Oxford and Cambridge was possible for students of 
a modern university. It was not until 1926 that Childs' work was crowned by the grant of university independence to the college at Reading. But the opening of Wantage Hall, which symbolized his most significant contribution to the idea of a modern university, was probably the event in his career from which ho derived the greatest pleasure, and it is the event which comes first to the memory of some, at least, of his associates on the morrow of his death.

F. M. Stextox.

\section{Prof. A. E. Kennelly}

WE regret to report the death on June 18 of Prof. Arthur Edwin Kennelly, emeritus professor of electrical engineering both at Harvard University and at the Massachusetts Institute of Technology. He had laboured for many years enthusiastically and successfully to further the interests of humanity by lightening manual and mental drudgery and promoting international co-operation for the interests of all. His work led him to associate with experimental and theoretical physicists, with mathematicians, inventors and engineers.

Kennelly was born at Bombay in India in June 1861 of British parentage. Ho was educated at private schools in Scotland, France and Belgium, and for four years at University College School, London. His first post was that of assistant secretary of the Society of Telegraph Engineers of London (now the Institution of Electrical Engineers). In 1876 he was a telegraph operator in England with the Eastern Telegraph Co. and in 1878 he was an electrician in Malta. In 1881 he was chief electrician in a cable engineering ship. In 1887 he went to the United States and became the principal electrical assistant to Thomas A. Edison, which position he held until 1894. In 1893 he was in addition consult. ing electrician to the Edison General Electric Co. (now the General Electric Co. of New York).

In 1902 Kennelly was appointed professor of electrical engineering at Harvard University and occupied that chair until his retirement as emeritus professor in 1930. During the years 1913-24 he was professor of electrical engineering at the Mas. sachusetts Institute of Technology, being appointed emeritus professor of that Institute also.

From 1894 until 1902 he was in partnership with E. J. Houston, the firm acting as consulting engineers. He was president of several societies, including the American Institute of Electrical Engineers, and the Illuminating Engineering Society during the early years of that organization. $\mathrm{He}$ was also president of the Metric Association.

In the international field, Kennelly's services havo been of the highest distinction. He was a United States delegate to the Electrical Congresses of 1900 , of 1904 , where he carried out the onerous duties of general secretary, and in 1932. He was also delegato to the International Radio Conferences in Paris in 1921 and in Washington in 1927, where allocations of radio transmission frequencies were made to the nations of the world. He was a member of the International Committee of Weights and Measures and attended the meeting at Sèvres in 1933. During the year 1921-22 he represented seven co-operating American universities as first 'exchange' professor in engineering and applied science at soveral French universities. In 1931 he gave a series of lectures in Japan under the Iwadare Foundation. $\mathrm{He}$ has published many books and is the author of more than 350 papers, many of which were presented before scientific organizations at home and abroad. He was unflagging in his attendance at committeo meetings and was the chairman of the committee on electrical definitions which has done very useful work.

In 1900, Kennelly was very interested in the progress made by Lodge, Fleming and Marconi in wireless transmission. When many mathematicians were proving that the transmission of wireless waves round the curvature of the earth was a physical impossibility, Marconi transmitted waves from Poldhu in Cornwall to Newfoundland. Kennelly, on March 15, 1902, was led to believe that the wireless waves were reflected by some kind of cloud producing a 'mirror' effect which bent the waves round the earth's surface. Kennelly and Heaviside both thought of a reflecting layer of ionized gas which could reflect the rays. This layer has since been called the Kennelly-Heaviside layer.

In 1924 Appleton demonstrated the real existence of a 'mirror' layer. 'The regular variation in reception, as the wave-length was changed, proved its existence, and later experiments proved that there was more than one reflecting layer in the atmosphere.

One of the most useful mathematical methods popularized by Kennelly was the use of Argand's method of using complex numbers to aid computers, thus saving much arithmetical labour. In April 1893 in a paper published by the A.I.F.E. under the title "Impedance", he applied complex qualities to technology and to the extension of Ohm's law to alternating current theory. He calls the inductanco multiplied by $2 \pi$ times the frequency, the "inductance speed". The impedance is therefore the geometrical or vector sum of the resistance and the inductance speed. We thus find what is often called the Ohm's law for alternating currents, which simplifies the everyday theory of the practical electrician. The impedance of inductive coils in series is readily determined, and when two or more inductive coils are in parallel the component currents are easily found. This can be done both graphically and algebraically. In the latter case, the solutions are expressed in terms of hyperbolic functions, which in the absence of tables are sometimes very laborious to compute. $\mathrm{He}$ therefore edited charts and tables of hyperbolic functions to several decimal places, for which there has been a great demand by practical electricians all over the world, as by the use of the tables and charts there is a great saving in the time taken by computers, and the accuracy required nowadays is much greater than that required thirty years ago. They are much used in long-distance telegraphy and telephony.

Kennelly was very popular with his old students, who used to go from all parts of the world to study under him. I remember that before the Great War 